\title{
Obituary.
}

Prof. John Cox.

THE death of Prof. John Cox at Hayes Court, Hayes, on May I3, removes an interesting personality from our midst. Prof. Cox devoted an active life to the cause of education and had a varied educational career, holding, at different times, the post of University extension lecturer, headship of a Cambridge college, and a professorship in physics in a Canadian University.

Born in $\mathrm{I} 85 \mathrm{I}$, Cox was a brilliant scholar of the City of London School under Dr. Abbott, where he was a contemporary and competitor for scholastic honours with his friend $H . H$. Asquith. He went as a scholar to Trinity College, Cambridge, and studied mathematics, being eighth wrangler in 1874 . Equally versed in classics, he took a good place in the Classical Tripos of the same year. He gained a fellowship at Trinity College on a dissertation in which he applied Hamilton's methods to some problems in geometrical optics. He was for ten years warden of Cavendish College, Cambridge a new College offering residential facilities to a younger class of undergraduates at a reduced cost. Ultimately the College was closed down, though some years after Cox had severed his connexion with it.

In $x 890$ Cox was appointed professor of physics in McGill University, Montreal. Previous to that time the physics had been taught with small facilities by Dr. Johnson, professor of mathematics. This appointment gave Cox a great opportunity, for it was at the time that McGill University was rapidly growing, through the munificent gifts of the late Sir William Macdonald. Ample funds were offered to build a new physics laboratory, and, before making plans, Cox was sent on a mission to study the physical laboratories in Europe and the United States. He threw himself with great energy into the new project, and the result was a well-designed laboratory which at the time of its opening was one of the finest and best equipped in the world. Under the impetus given by the appointment of Callendar and afterwards of Rutherford, the laboratory became a centre of research in physical science, and Cox followed with pride and enthusiasm the pioneer researches of Rutherford and Soddy on radioactivity.

While keenly interested in all developments of physics, Cox had not the practical training requisite for research in experimental physics, but devoted himself to the teaching and administrative side. A fluent and polished speaker, he was an admirable lecturer, and as a speaker for popular audiences on scientific and general topics he had few superiors. It was characteristic of his temperament that he was somewhat dilatory in ordinary business matters and often required the spur of necessity to deal with correspondence. A man of wide interests and wide social sympathies he exercised a strong influence for good both in Montreal and the University. In I909 he retired from $\mathrm{McGill}$ with a Carnegie pension to live in England, and was awarded the honorary degree of LL.D. by McGill University. He immediately took up the work of lecturing for the Oxford Extension Delegacy and particularly for the Gilchrist Trust. This was a type of work which he thoroughly enjoyed and carried out with great enthusiasm and success. During the War, he offered his services to the Ministry of Munitions and assisted in the work of the munition tribunals.

After the death of his wife, Cox lived at Hayes Court with a daughter. He retained his enthusiasm for science to the end and, before his illness became acute, followed with keen interest the work of Einstein and Bohr. Of his publications, the best known is his book on mechanics published by the Cambridge University Press. This useful work was written on novel lines, being largely influenced by the writings of Marx, of whom he was an admirer. Another small book, "Beyond the Atom," gives a vivid account of the bearing of the earlier radioactive researches, with which he had come in contact in Montreal, on the structure of matter. A man of fine character, of attractive personality and varied gifts, his unexpected end will be mourned by a wide circle of friends. He leaves two daughters and a son, who is a mining engineer in Canada.

\section{Mr. R. W. HOOLEY}

Mr. Reginald William Hooley, whose death on May 5 at the age of fifty-seven we regret to record, devoted many years to the study of the geology of the Isle of Wight, and to the systematic exploration of the Wealden rocks of the south coast. He made an important collection of the remains of reptiles and fishes from the cliffs between Brook and Atherfield, and established a small museum at his residence at Winchester. He also acquired an excellent knowledge of the Wealden reptiles, which he extricated from the hard rock with great skill, and he wrote several important papers on his specimens. He described new Chelonia in the Geological Magazine in 1897 and r9oo.

In I904 Mr. Hooley was elected a fellow of the Geological Society, and he contributed papers on unique specimens of the crocodile Goniopholis and the pterodactyl Ornithodesmus to the Society's Quarterly Journal in 1907 and 1913 . During recent years he discovered and prepared a skeleton of Iguanodon, in some respects finer than the well-known specimens at Brussels and showing parts of the skin. Of this remarkable fossil he wrote an exhaustive memoir, illustrated by his own drawings, which he had intended to read to the Geological Society at a recent meeting.

Mr. Hooley was an indefatigable worker, with only scanty leisure to devote to science, and his premature death is regretted by the large circle of geologists and palæontologists who enjoyed his friendship and co-operation. His specimens of Goniopholis and Ornithodesmus are already in the Geological Department of the British Museum (Natural History), and the rest of his collection is destined to be added to them.

A. S. W.

WE regret that the date of the death of Mr. F. W. Harmer was given incorrectly in NATURE of June 9 as April 24: it should have been April II.

NO. 2798 , VOL. I I I] 